\title{
Pengaruh Pemberian Emras Terhadap Pertumbuhan dan Hasil Tanaman Buncis (Phaseolus vulgaris L.) pada Lahan Rawa Lebak
}

\section{(Effect of Emras on Plant Growth and Yield Beans (Phaseolus vulgaris L.) in Lebak Wetland)}

\author{
Zarmiyeni' $^{1)}$, Farida Adriani' ${ }^{2)}$ \& Majedi $^{3)}$ \\ Program Studi Agroteknologi, Sekolah Tinggi Ilmu Pertanian Amuntai \\ ${ }^{1)}$ zarmiyenilg@gmail.com \\ ${ }^{2)}$ Adrianifr9@gmail.com \\ ${ }^{3)}$ Majedi214@yahoo.co.id
}

\begin{abstract}
ABSTRAK
Buncis merupakan sejenis polong-polongan yang dapat dimakan. Buncis ini kaya dengan kandungan protein dan vitamin yang membantu menurunkan tekanan darah serta mengawal metabolisme gula dalam darah dan amat sesuai dimakan oleh mereka yang mengidap penyakit diabetes atau hipertensi. Kandungan serat dan enzim yang tinggi dapat membantu penurunan berat badan. Dalam membudidayakan buncis perlu dioptimalkan mengingat kebutuhan konsumsi tidak sebanding dengan produksinya. Salah satu cara untuk meningkatkan produktivitas tanaman buncis adalah dengan pemupukan yang tepat, diantaranya dengan penggunaan pupuk organik. . Tujuan penelitian (i) mengetahui pengaruh dan (ii) Mendapatkan konsentrasi terbaik di antara pemberian EMRAS terhadap pertumbuhan dan hasil tanaman buncis pada lahan rawa lebak. Penelitian ini dilaksanakan pada lahan rawa lebak yang ada di Desa Teluk Buluh Kecamatan Banjang Kabupaten Hulu Sungai Utara pada bulan Mei - Juli 2013, menggunakan Rancangan Acak Kelompok (RAK), dengan 6 taraf perlakuan dan 4 kelompok, sehingga diperoleh 24 satuan percobaan dan setiap percobaan terdiri dari 2 tanaman sampel, sehingga total sampel ada 48 tanaman. Faktor yang diuji adalah pemberian EMRAS, $e_{0}=0 \%(0 \mathrm{l} / \mathrm{bedengan}), e_{1}=25 \%(0,25$ l/bedengan $), e_{2}=50 \%$ (0,5 l/bedengan), $e_{3}=75 \%$ (0,75 l/bedengan $), e_{4}=100 \%$ ( 1 l/bedengan $)$ dan $e_{5}=$ $125 \%$ (1,25 l/bedengan). Hasil penelitian menunjukkan bahwa pemberian EMRAS berpengaruh pada peubah tinggi tanaman, jumlah cabang produktif, jumlah polong pertanaman, dan bobot basah polong pertanaman dengan pemberian terbaik didapati pada konsentrasi 100\% (1 1/bedengan).
\end{abstract}

Kata kunci: Buncis, EMRAS, lahan, rawa, lebak

\section{ABSTRACT}

Beans are a kind of edible beans. Beans are rich in protein and vitamins that help lower blood pressure and monitor blood sugar metabolism and are equated with being eaten by those who suffer from diabetes or hypertension. High fiber and enzyme content can help you lose weight. In peanut cultivation it needs to be optimized considering the consumption needs are not comparable with production, One way to increase the productivity of peanut plants is proper fertilization, such as by using organic fertilizers. This study aims (i) to determine the effect of EMRAS on the growth and yield of beans (Phaseolus vulgaris L.) on swampy swamp land. (ii) Getting the best concentration between EMRAS and growth and yield of beans (Phaseolus vulgaris L.) on swamp swamp land. This research was carried out on swamp swamp land in Teluk Buluh Village, Banjang District, Hulu Sungai Utara Regency in May - July 2013, using a Randomized Block Design (RBD), with 6 treatments and 4 replications, resulting in 24 experimental units and each experiment. consists of 2 sample plants, so that the total sample is 48 plants. The factors tested were the provision of EMRAS, $e_{0}=0 \%(0 \mathrm{l} / \mathrm{beds}), e_{1}=25 \%(0,25 \mathrm{l} / \mathrm{beds}), e_{2}=50 \%(0,5 \mathrm{l} / \mathrm{beds}), e_{3}=75 \%(0,75$ l/beds $), e_{4}=100 \%(1 \mathrm{l} / \mathrm{beds})$ and $e_{5}=125 \%(1,25 \mathrm{l} / \mathrm{beds})$. The results showed that the observation variables of EMRAS administration affected plant height, number of productive branches, number of pods per plant, and pod wet weight per plant with the best administration at $100 \%$ concentration $(1 \mathrm{l} / \mathrm{bed})$.

Keywords: Beans, EMRAS, land, wetland, lebak

\section{PENDAHULUAN}

Buncis merupakan sejenis polongpolongan yang dapat dimakan. Buncis ini kaya dengan kandungan protein dan vitamin yang membantu menurunkan tekanan darah 
serta mengawal metabolisme gula dalam darah dan amat sesuai dimakan oleh mereka yang mengidap penyakit diabetes atau hipertensi. Kandungan serat dan enzim yang tinggi dapat membantu penurunan berat badan (Wikipedia, 2010).

Berdasarkan data Statistik dari Dinas Pertanian Tanaman Pangan dan Hortikultura Kabupaten Hulu Sungai Utara untuk komoditas tanaman buncis belum terdata. Sehingga hal ini menjadi gambaran bahwa pengembangan jenis tanaman ini masih belum ada dan menjadi bahan rujukan bagi dinas terkait untuk mulai mengupayakan untuk mencoba mengembangkannya.

Rawa lebak adalah wilayah daratan yang mempunyai genangan hampir sepanjang tahun, minimal selama tiga bulan dengan tinggi genangan minimal $50 \mathrm{~cm}$. Rawa lebak yang dimanfaatkan atau dibudidayakan untuk pengembangan pertanian, termasuk perikanan dan peternakan disebut lahan rawa lebak (Noor, 2007).

Menurut Ragil (2012), penurunan kesuburan tanah dapat diakibatkan banyak hal, salah satunya adalah pengolahan tanah yang kurang baik, penggunaan pupuk anorganik yang berlebihan dan pengangkutan bahan organik dari panen yang tidak seimbang dengan pemasukan bahan organik di dalam tanah dan lain sebagainya, sehingga dapat mengakibatkan tanah-tanah yang terdapat sekarang ini semakin menurun kandungan unsur haranya. Salah satu cara untuk meningkatkan produktivitas tanaman buncis adalah dengan pemupukan yang tepat, diantaranya dengan penggunaan pupuk organik EMRAS.

Berdasarkan Hasil Analisis Tanah Laboratorium Kimia, Fisika, dan Biologi UNLAM (2013), tanah rawa lebak yang ada di Desa Teluk Buluh Kecamatan Banjang mempunyai kandungan C-Organik 0,91\% (rendah), $\mathrm{N}$ Total $0,21 \%$ (sedang), $\mathrm{P}$ Total $39,43 \mathrm{me} / 100 \mathrm{~g}$ (sedang), $\mathrm{K}$ Total 18,21 $\mathrm{mg} / 100 \mathrm{~g}$ (rendah), Al 1,43 me/100 $\mathrm{g}$ (sedang), Fe larut 201,11 ppm (tinggi), Ca $12,90 \mathrm{me} / 100 \mathrm{~g}$ (rendah), $\mathrm{Mg} \mathrm{0,30} \mathrm{me/100} \mathrm{g}$ (sedang), KTK 29,02 me/100 g (tinggi), dan pH 4,39 (masam). Hal ini dapat menyebabkan tanah kurang unsur hara dan pertumbuhan tanaman menjadi terhambat, untuk mengatasi permasalah ini maka pemberian pupuk perlu untuk menunjang keberhasilan budidaya tanaman buncis.

Berdasarkan paparan permasalahan tanah pada lahan rawa lebak serta solusi pengelolaannya melalui pemupukan, maka telah dilaksanakan penelitian tentang pengaruh pemberian EMRAS terhadap pertumbuhan dan hasil tanaman buncis pada lahan rawa lebak.

Tujuan penelitian ini adalah (i) mengetahui pengaruh pemberian EMRAS terhadap pertumbuhan dan hasil tanaman buncis pada lahan rawa lebak, dan (ii) mendapatkan konsentrasi terbaik di antara pemberian EMRAS terhada pertumbuhan dan hasil tanaman buncis pada lahan rawa lebak.

\section{METODE PENELITIAN}

Penelitian ini telah dilaksanakan pada lahan rawa lebak yang ada di Desa Teluk Buluh Kecamatan Banjang Kabupaten Hulu Sungai Utara pada bulan Mei - Juli 2013. Bahan dan alat yang digunakan adalah tanah pada lahan rawa lebak, benih buncis, emras, pestisida. Alat-alat yang digunakan adalah parang, cangkul, tali, gembor, turus/ajir, hand sprayer, alat pengukur, alat tulis dan kamera.

\section{Rancangan Percobaan}

Penelitian ini merupakan percobaan lapangan yaitu Rancangan Acak Kelompok (RAK). Rancangan percobaan dengan faktor tunggal dengan konsentrasi EMRAS (e) sebagai perlakuan (treatment) sebanyak 6 taraf yaitu : $\mathrm{e}_{0}=0 \%$ setara dengan 0 1/bedengan $\mathrm{e}_{1}=25 \%$ setara dengan 0,25 1/bedengan, $e_{2}=50 \%$ setara dengan 0,5 1/bedengan, $e_{3}=75 \%$ setara dengan 0,75 1/bedengan, $e_{4}=100 \%$ setara dengan 1 1/bedengan, $e_{5}=125 \%$ setara dengan 1,25 1/bedengan. Masing-masing perlakuan diulang dengan 4 kali ulangan, sehingga diperoleh 24 satuan satuan percobaan dan setiap satuan percobaan terdiri dari 2 tanaman sampel. 


\section{Pelaksanaan Penelitian}

Pelaksanaan penelitian meliputi persiapan, pengolahan tanah, pemupukan, penanaman, pemberian perlakuan, pemeliharaan, panen. Pengamatan tinggi tanaman, jumlah cabang produktif, jumlah polong per tanaman bobot basah polong per tanaman.

Hasil percobaan dari semua peubah yang diamati datanya dikumpulkan, kemudian dihitung secara statistik dengan menggunakan sidik ragam (Anova). Apabila hasil analisis tersebut berpengaruh nyata maka dilanjutkan dengan Uji Duncan's New Multiple Rage Test (DNMRT) taraf 5\% (Steel dan Torrie, 1994 dalam Ragil, 2012).

\section{HASIL DAN PEMBAHASAN}

\section{Hasil}

\section{Tinggi Tanaman}

Berdasarkan hasil analisis ragam peubah data yang diamati menunjukkan bahwa pemberian EMRAS tidak berpengaruh nyata terhadap tinggi tanaman pada umur 7 dan 14 HST, berpengaruh nyata terhadap tinggi tanaman pada umur 21 HST dan berpengaruh sangat nyata terhadap tinggi tanaman umur 28 HST. Rerata tinggi tanaman umur 7, 14, 21 dan 28 HST disajikan pada Tabel 1.

Tabel 1. Pengaruh pemberian EMRAS terhadap rerata tinggi tanaman buncis umur 7, 14, 21 dan 28 HST

\begin{tabular}{ccccc}
\hline Konsentrasi & \multicolumn{4}{c}{ Rerata Tinggi Tanaman $(\mathrm{cm})$} \\
\cline { 2 - 5 } EMRAS & $7 \mathrm{HST}$ & $14 \mathrm{HST}$ & $21 \mathrm{HST}$ & $28 \mathrm{HST}$ \\
\hline $\mathrm{e}_{0}(0 \%)$ & 17,00 & 34.44 & $89,69^{\mathrm{a}}$ & $107,88^{\mathrm{a}}$ \\
$\mathrm{e}_{1}(25 \%)$ & 19,25 & 36.31 & $91,31^{\mathrm{a}}$ & $111,06^{\mathrm{ab}}$ \\
$\mathrm{e}_{2}(50 \%)$ & 20,69 & 39.44 & $92.00^{\mathrm{a}}$ & $113,88^{\mathrm{ab}}$ \\
$\mathrm{e}_{3}(75 \%)$ & 17,25 & 42.44 & $108,88^{\mathrm{ab}}$ & $124,19^{\mathrm{bc}}$ \\
$\mathrm{e}_{4}(100 \%)$ & 18,56 & 49.31 & $123,31^{\mathrm{b}}$ & $136,94^{\mathrm{c}}$ \\
$\mathrm{e}_{5}(125 \%)$ & 16,38 & 39.88 & $102,75^{\mathrm{a}}$ & $116,19^{\mathrm{ab}}$ \\
\hline
\end{tabular}

Keterangan: Nilai rerata yang diikuti huruf superscript yang sama pada kolom yang sama menunjukkan perlakuan tersebut tidak berbeda nyata berdasarkan uji DMRT pada taraf nyata $5 \%$.

Dari Tabel 1 terlihat bahwa pemberian EMRAS menghasilkan adanya peningkatan rerata tinggi tanaman yang cukup signifikan pada umur 7, 14, 21 dan 28 HST. Pemberian EMRAS pada konsentrasi (e 4 ) $100 \%$ menunjukkan pada umur 21 dan 28 HST rerata tinggi tanaman paling tinggi dibandingkan dengan konsentrasi $\left(\mathrm{e}_{0}\right) 0 \%$, (e 1 ) $25 \%,\left(e_{2}\right) 50 \%,\left(e_{3}\right) 75 \%$, dan (e $\left.e_{5}\right) 125 \%$.

\section{Jumlah Cabang Produktif}

Berdasarkan hasil analisis ragam menunjukkan bahwa pemberian EMRAS berpengaruh nyata terhadap jumlah cabang produktif. Rerata jumlah cabang produktif dapat dilihat pada Tabel 2 . 
Tabel 2. Pengaruh pemberian EMRAS terhadap rerata jumlah cabang produktif

\begin{tabular}{cc}
\hline Konsentrasi EMRAS & Rerata Jumlah Cabang Produktif (buah) \\
\hline e0 $(0 \%)$ & $1,13 \mathrm{a}$ \\
e1 $(25 \%)$ & $1,38 \mathrm{a}$ \\
e2 $(50 \%)$ & $1,38 \mathrm{a}$ \\
e3 $(75 \%)$ & $1,63 \mathrm{a}$ \\
e4 $(100 \%)$ & $2,50 \mathrm{~b}$ \\
e5 $(125 \%)$ & $1,50 \mathrm{a}$ \\
\hline
\end{tabular}

Keterangan: Nilai rerata yang diikuti huruf superscript yang sama pada kolom yang sama menunjukkan perlakuan tersebut tidak berbeda nyata berdasarkan uji DMRT pada taraf nyata $5 \%$.

Dari Tabel 2 terlihat bahwa pemberian EMRAS berpengaruh terhadap peningkatan rerata jumlah cabang produktif. Pemberian EMRAS pada konsentrasi $\left(\mathrm{e}_{4}\right) \quad 100 \%$ menunjukkan rerata jumlah cabang produktif paling banyak dibandingkan dengan konsentrasi $\left(\mathrm{e}_{0}\right) 0 \%,\left(\mathrm{e}_{1}\right) 25 \%,\left(\mathrm{e}_{2}\right) 50 \%,\left(\mathrm{e}_{3}\right)$ $75 \%$, dan $\left(\mathrm{e}_{5}\right) 125 \%$.

\section{Jumlah Polong Per Tanaman}

Berdasarkan hasil analisis ragam menunjukkan bahwa pemberian EMRAS berpengaruh nyata terhadap jumlah polong per tanaman pada panen pertama dan berpengaruh sangat nyata terhadap jumlah polong per tanaman pada panen kedua. Rerata jumlah polong per tanaman pada panen pertama dan kedua dapat dilihat pada tabel berikut ini.

Tabel 3. Pengaruh pemberian EMRAS terhadap rerata jumlah polong per tanaman pada panen pertama dan kedua

\begin{tabular}{ccc}
\hline Konsentrasi & \multicolumn{2}{c}{ Jumlah Polong Per Tanaman (buah) } \\
\cline { 2 - 3 } EMRAS & Panen ke-1 & Panen ke-2 \\
\hline $\mathrm{e}_{0}(0 \%)$ & $4,50^{\mathrm{a}}$ & $7,50^{\mathrm{a}}$ \\
$\mathrm{e}_{1}(25 \%)$ & $8,38^{\mathrm{bc}}$ & $9,88^{\mathrm{b}}$ \\
$\mathrm{e}_{2}(50 \%)$ & $6,00^{\mathrm{ab}}$ & $9,00^{\mathrm{ab}}$ \\
$\mathrm{e}_{3}(75 \%)$ & $6,88^{\mathrm{abc}}$ & $11,38^{\mathrm{bc}}$ \\
$\mathrm{e}_{4}(100 \%)$ & $10,25^{\mathrm{c}}$ & $13,25^{\mathrm{c}}$ \\
$\mathrm{e}_{5}(125 \%)$ & $7,13^{\mathrm{abc}}$ & $10,13^{\mathrm{b}}$ \\
\hline
\end{tabular}

Keterangan: Nilai rerata yang diikuti huruf superscript yang sama pada kolom yang sama menunjukkan perlakuan tersebut tidak berbeda nyata berdasarkan uji DMRT pada taraf nyata $5 \%$.

Dari Tabel 3 terlihat bahwa pemberian EMRAS menghasilkan adanya peningkatan jumlah polong per tanaman pada panen pertama dan kedua. Pemberian EMRAS pada konsentrasi $\left(\mathrm{e}_{4}\right)$ 100\% menunjukkan rerata jumlah polongf per tanaman paling banyak dibandingkan dengan konsentrasi $\left(\mathrm{e}_{0}\right) 0 \%$, (e 1 ) $25 \%,\left(e_{2}\right) 50 \%,\left(e_{3}\right) 75 \%$, dan $\left(e_{5}\right) 125 \%$.

\section{Bobot Basah Polong Per Tanaman}

Berdasarkan hasil analisis ragam menunjukkan bahwa pemberian EMRAS berpengaruh sangat nyata terhadap bobot basah polong per tanaman pada panen pertama dan kedua. Rerata bobot basah polong per tanaman pada panen pertama dan kedua disajikan pada Tabel 4. 
Tabel 4. Pengaruh pemberian EMRAS terhadap rerata bobot basah polong per tanaman pada panen pertama dan kedua

\begin{tabular}{ccc}
\hline Konsentrasi & \multicolumn{2}{c}{ Bobot Basah Polong Per Tanaman $(\mathrm{g})$} \\
\cline { 2 - 3 } EMRAS & Panen ke-1 & Panen ke-2 \\
\hline $\mathrm{e}_{0}(0 \%)$ & $15,00^{\mathrm{a}}$ & $21,00^{\mathrm{a}}$ \\
$\mathrm{e}_{1}(25 \%)$ & $29,00^{\mathrm{bc}}$ & $29,50^{\mathrm{ab}}$ \\
$\mathrm{e}_{2}(50 \%)$ & $20,75^{\mathrm{ab}}$ & $26,75^{\mathrm{ab}}$ \\
$\mathrm{e}_{3}(75 \%)$ & $23,50^{\mathrm{bc}}$ & $35,00^{\mathrm{bc}}$ \\
$\mathrm{e}_{4}(100 \%)$ & $36,50^{\mathrm{c}}$ & $42,50^{\mathrm{c}}$ \\
$\mathrm{e}_{5}(125 \%)$ & $25,25^{\mathrm{bc}}$ & $31,25^{\mathrm{b}}$ \\
\hline
\end{tabular}

Keterangan: Nilai rerata yang diikuti huruf superscript yang sama pada kolom yang sama menunjukkan perlakuan tersebut tidak berbeda nyata berdasarkan uji DMRT pada taraf nyata $5 \%$.

Dari Tabel 4 terlihat bahwa pemberian EMRAS menghasilkan adanya peningkatan bobot basah polong per tanaman dari panen pertama dan kedua. Pemberian EMRAS pada konsentrasi $\left(\mathrm{e}_{4}\right) \quad 100 \%$ menunjukkan rerata jumlah cabang produktif paling banyak dibandingkan dengan konsentrasi $\left(\mathrm{e}_{0}\right) 0 \%$, (e 1 ) $25 \%,\left(e_{2}\right) 50 \%,\left(e_{3}\right) 75 \%$, dan $\left(e_{5}\right) 125 \%$.

\section{Pembahasan}

\section{Tinggi Tanaman}

Berdasarkan analisis ragam terlihat bahwa pemberian EMRAS menunjukkan tidak berpengaruh nyata pada tinggi tanaman umur 7 dan 14 HST, sedangkan pada umur 21 HST menunjukkan pengaruh nyata pada umur $21 \mathrm{HST}$ dan berpengaruh sangat nyata pada umur 28 HST.

Pemberian EMRAS tidak berpengaruh terhadap tinggi tanaman pada umur 7 dan 14 HST, hal ini diduga pada awal pertumbuhan tanaman buncis mampu memenuhi kebutuhan makanan yang disuplai dari kotiledon (cadangan makanan) yang masih menempel pada batang dan juga akar tanaman belum berkembang sehingga belum mampu menyerap unsur hara dari dalam tanah secara optimal.

Berbeda dengan hal di atas, pemberian EMRAS berpengaruh nyata pada umur 21 HST, dan berpengaruh sangat nyata pada umur 28 HST. Hal ini selain dikarenakan perakaran sudah berkembang dan aktif dalam menyerap unsur hara, juga diduga EMRAS sudah terdekomposisi sempurna maka sudah bisa diserap dan dipergunakan oleh tanaman sehingga tinggi tanaman tumbuh secara pesat.

Hasil analisis Laboratorium Kimia, Fisika, dan Biologi Tanah Fakultas Pertanian Universitas Lambung Mangkurat (2013), lahan rawa lebak di desa Teluk Buluh Kecamatan Banjang Kabupaten Hulu Sungai Utara mengandung unsur hara nitrogen yang sedang yaitu 0,11 , fosfor yang sedang yaitu 39,43 dan kalium yang rendah yaitu 18,21. Sedangkan pada air cucian beras mengandung unsur hara nitrogen 0,015\% (rendah), fosfor $16,306 \%$ (tinggi) dan kalium $0,02 \%$ (rendah).

Menurut Jumin (2002) dalam Irfan, et.al., (2012) fungsi nitrogen (N) adalah meningkatkan pertumbuhan vegetatif dimana nitrogen berfungsi untuk merangsang pertumbuhan tanaman terutama batang dan daun. Tanaman yang kekurangan unsur $\mathrm{N}$ pertumbuhannya lambat dan kerdil (Novizan, 2002).

Unsur fosfor (P) membantu dalam proses pertumbuhan akar. Kekurangan unsure $\mathrm{P}$ menyebabkan pertumbuhan tanaman lambat dan kerdil, perkembangan akar terhambat, serta pertumbuhan daun tidak normal (Novizan, 2002).

Unsur kalium (K) berfungsi mempercepat pertumbuhan jaringan meristem. Kekurangan unsur $\mathrm{K}$ maka daun terlihat lebih tua dan mudah rontok, batang ataupun cabang lemah dan mudah rebah (Novizan, 2002). 
Kandungan unsur hara lain yang terdapat pada air cucian beras yaitu besi, magnesium, kalsium, mangan, dan seng. Menurut Rioardi (2009), Fe diserap dalam bentuk ion feri $\left(\mathrm{Fe}^{3+}\right)$ ataupun fero $\left(\mathrm{fe}^{2+}\right)$ berperan dalam perkembangan kloroplas. $\mathrm{Mg}$ yang terkandung dalam air cucian beras berfungsi membantu proses pembentukan hijau daun atau klorofil dan berperan membantu transportasi phosphate dalam tanaman (Astutik, 2009). Magnesium merupakan unsur esensial penyusun klorofil serta berperan sebagai kofaktor dalam sebagian besar enzim yang menggiatkan proses fosforilasi, sebagai jembatan antara struktur pirofosfat dari ATP dan ADP dan molekul enzim dan menstabilkan partikel dalam konfigurasi untuk sintesis protein.

Kalsium merupakan penyusun dinding sel, berperan dalam pemeliharaan integritas sel dan permeabilitas membran. Menurut Astutik (2009), Ca berfungsi sebagai pengatur pengisapan air dari dalam tanah, berguna untuk menghilangkan racun dalam tanah, Ca juga berfungsi pada pertumbuhan vegetatif tanaman. Kekurangan unsur $\mathrm{Ca}$ dapat menyebabkan matinya titik tumbuh pada pucuk dan akar tanaman (Novizan, 2002).

Menurut Astutik (2009), fungsi mangan adalah pada proses fotolisis air (penguraian air) sehingga terbentuk energi yang dapat digunakan tanaman untuk prosesproses metabolisme seperti absorrbsi, transpirasi, pembelahan sel, pembungaan dan pembentukan buah. Seng dalam jumlah yang sangat sedikit dapat berperan dalam perkembangan pertumbuhan, diperkirakan persenyawaan $\mathrm{Zn}$ berfungsi dalam pembentukan hormone tumbuh dan penting bagi keseimbangan fisiologis, berperan dalam pertumbuhan vegetatif seperti pemanjangan sel dan ruas batang serta berperan dalam pertumbuhan biji atau buah (Maspary, 2010 dalam Hermayanti, 2011).

\section{Jumlah Cabang Produktif}

Berdasarkan analisis ragam terlihat bahwa pemberian EMRAS menunjukkan berpengaruh nyata terhadap rerata jumlah cabang produktif. Hasil analisis Laboratorium Kimia, Fisika, dan Biologi
Tanah Fakultas Pertanian Universitas Lambung Mangkurat (2013), lahan rawa lebak di Desa Teluk Buluh Kecamatan Banjang Kabupaten Hulu Sungai Utara mengandung unsur hara nitrogen yang sedang yaitu $0,11 \%$.

Senyawa nitrogen digunakan tanaman untuk membentuk asam amino yang akan diubah menjadi protein. Selain itu, juga dibutuhkan untuk membentuk senyawa penting seperti klorofil, asam nukleat, dan enzim. Oleh karena itu, nitrogen diperlukan dalam jumlah besar pada setiap tahap pertumbuhan, salah satunya pembentukan percabangan (Novizan, 2002).

\section{Jumlah Polong dan Bobot Basah Per Tanaman}

Berdasarkan analisis ragam terlihat bahwa pemberian EMRAS menunjukkan berpengaruh nyata terhadap rerata jumlah polong per tanaman pada panen pertama dan berpengaruh sangat nyata terhadap rerata jumlah polong per tanaman pada panen kedua. Sedangkan pemberian EMRAS berpengaruh sangat nyata terhadap bobot basah per tanaman pada panen pertama dan kedua.

Hasil analisis Laboratorium Kimia, Fisika, dan Biologi Tanah Fakultas Pertanian Universitas Lambung Mangkurat (2013), lahan rawa lebak di Desa Teluk Buluh Kecamatan Banjang Kabupaten Hulu Sungai Utara mengandung unsur hara nitrogen yang sedang yaitu $0,11 \%$, fosfor yang sedang yaitu 55,14 dan kalium yang rendah yaitu 18,21, sedangkan pada air cucian beras mengandung unsur hara nitrogen sebesar $0,015 \%$, fosfor sebesar $16,306 \%$ dan kalium sebesar $0,02 \%$.

Nitrogen merupakan unsur hara utama bagi pertumbuhan tanaman, yang pada umumnya sangat diperlukan untuk pembentukan atau pertumbuhan bagianbagian vegetatif tanaman seperti daun, batang dan akar, tetapi apabila terlalu banyak dapat menghambat pembungaan dan pembuahan pada tanaman.

Di dalam tanaman antara unsur P dan $\mathrm{K}$ saling ketergantungan. Unsur $\mathrm{K}$ berperan dalam transport unsur hara keseluruh jaringan tanaman, termasuk hara $\mathrm{P}$ ke daun 
dan mentranslokasi asimilat dari daun keseluruh jaringan tanaman. Tanaman dapat membentuk ATP secara optimal bila serapan hara P juga optimal. Menurut Evita (2009), menjelaskan bahwa pengaruh pupuk cair meningkatkan jumlah polong per tanaman, berat segar polong per tanaman, berat kering tanaman dan produksi karena unsur hara mikro yang terkandung langsung di absorbsi, di translokasikan dan kemudian dipergunakan oleh tanaman.

Menurut Gardner (1991) dalam Irfan, et, al., (2012), pemupukan $\mathrm{P}$ dapat meningkatkan hasil panen, selain itu menurut Lakitan (2000) dalam Irfan, et, al.,(2012), fospor merupakan senyawa pembentuk gula fospat yang esensial pada reaksi fase gelap, fotosintesis, respirasi, dan proses metabolisme lainnya.

Hal tersebut sesuai dengan laporan Mitra et, al. (1990) dalam Irfan, et, al.,(2012), menyatakan bahwa pemberian fosfat pada tanaman buncis dapat meningkatkan produksi polong. Gavras (1990) dalam Irfan, et, al., (2012), menyatakan bahwa pupuk yang mengandung fosfor telah terbukti efektif dalam hal perkembangan akar pada tahap pertama pertumbuhan dan setelah itu mereka memiliki efek positif pada hasil polong dan kualitas kacang buncis. Penampakan fisik polong yang besar dan bernas terjadi karena cadangan makanan yang ditimbun di polong semakin banyak.

\section{KESIMPULAN}

Diketahui adanya pengaruh pemberian EMRAS terhadap pertumbuhan dan hasil tanaman buncis pada lahan rawa lebak. Didapati konsentrasi sebanyak 100\% (1 1/bedengan) terhadap tanaman buncis pada lahan rawa lebak merupakan konsentrasi terbaik pada variabel pengamatan tinggi tanaman, jumlah cabang produktif, jumlah polong per tanaman dan bobot basah polong per tanaman.

\section{DAFTAR PUSTAKA}

Astutik, S. 2009. Beras Coklat (Brown Rice) atau Beras Pecah Kulit. http://ksuointer.com. Diakses tanggal 12 Oktober 2013.

Evita. 2009. Pertumbuhan dan hasil tanaman kacang buncis (Phaseolus vulgaris L.) terhadap pemberian pupuk cair petrovita. J. Percikan 96: 65-68

Hermayanti. 2011. Efektivitas Pemberian Air Cucian Beras coklat terhadap produktivitas tanaman kacang hijau (Phaseolus radiatus L.) pada lahan rawa lebak. Skripsi. Stiper Amuntai. Amuntai.

Irfan, N.M, Ardian, dan Armaini. 2012. Pengaruh pemberian fermentasi alami air cucian beras terhadap pertumbuhan dan produksi tanaman jagung manis (Zea mays L Var saccharata Sturt). Jurnal Penelitian. Fakultas Pertanian Universitas Riau.

Laboratorium Kimia, Fisika, dan Biologi Tanah Fakultas Pertanian Universitas Lambung Mangkurat. 2013. Hasil Analisis Tanah Pada Lahan Rawa Lebak Desa Karias Tabing Kecamatan Banjang. Banjarbaru.

Noor, M. 2007. Lebak; Ekologi, Pemanfaatan dan Pengembangannya. PT. Raja Grafindo Persada. Jakarta.

Novizan. 2002. Petunjuk Pemupukan Efektif. Agromedia. Jakarta.

Ragil, D. 2012. Pengaruh pemberian zeolit terhadap pertumbuhan dan hasil tanaman buncis (Phaseolus vulgaris. L). http://dionragil.blogspot.com/. Diakses pada tanggal 09 Mei 2013.

Wikipedia. $2010 . \quad$ Buncis. http://id.m.wikipedia.org. Diakses tanggal 07 April 2013. 